\title{
Induksi kalus Artemisia vulgaris L. dengan Pemberian Beberapa Konsentrasi 2,4-Dichlorophenoxyacetic Acid (2,4-D)
}

\section{Callus Induction of Artemisia vulgaris L. by Addition of Several Concentration of 2,4-Dichlorophenoxyacetic acid (2,4-D)}

\author{
Nazhira Fadhilah*) Zozy Aneloi Noli dan Suwirmen
}

Laboratorium Fisiologi Tumbuhan dan Kultur Jaringan, Jurusan Biologi FMIPA Universitas Andalas

*Koresponden: Nazhira1110421002@gmail.com

\begin{abstract}
The research about callus induction Artemisia vulgaris L. by giving several concentration 2,4Dichlorophenoxyacetic acid (2,4-D), has been done from May to August 2015 in Plant Physiology Laboratory and Tissue Culture, Department of Biology, Faculty of Mathematics and Natural Science, University of Andalas. The aim of this study was found the effective concentration of 2,4-D to induce callus of A. vulgaris. The research used Completely Randomized Design (CRD) with 7 treatments and 4 replications. The treatments were : without 2,4-D (control); $0.25 \mathrm{mg} / \mathrm{L} \mathrm{2,4-D;} 0.50 \mathrm{mg} / \mathrm{L}$ 2,4-D; $0.75 \mathrm{mg} / \mathrm{L}$ 2,4-D; $1.00 \mathrm{mg} / \mathrm{L} \mathrm{2,4-D;} 1.25$ $\mathrm{mg} / \mathrm{L} 2,4-\mathrm{D} ; 1.5 \mathrm{mg} / \mathrm{L} 2,4-\mathrm{D}$. The result showed that $0.25-1,5 \mathrm{mg} / \mathrm{L} 2,4-\mathrm{D}$ were able induction callus of A. vulgaris, with compact until the friable texture, color of the resulting callus is yellowish green, brownish-green, yellow-brown, white yellowish and greenish white. 2,4-D 1.5 $\mathrm{mg} / \mathrm{L}$ was the best concentration to increase fresh weight of callus.
\end{abstract}

Keywords : Artemisia vulgaris L.,Callus 2,4-D

\section{Pendahuluan}

Malaria merupakan salah satu penyebab utama tingginya angka kematian diberbagai negara. Diperkirakan 1,5 juta hingga 2,7 juta jiwa meninggal setiap tahunnya akibat penyakit malaria diseluruh dunia. Daerah subtropis dan tropis merupakan daerah yang beresiko tinggi terhadap penyakit malaria. Indonesia merupakan salah satu negara di kawasan tropis dan merupakan daerah endemis untuk malaria serta memiliki resiko penyebaran yang cukup signifikan (Ishak, 2005).

Selama ini penanganan terhadap penyakit malaria menggunakan pil kina, senyawa klorokuin dan sulfadoksinpirimetamin. Akan tetapi, telah terjadinya resistensi Plasmodium falciparum yaitu protozoa penyebab penyakit malaria terhadap senyawa tersebut (Harijanto, 2011). Ditemukannya alternatif senyawa baru sebagai anti malaria yang lebih efektif menjadi harapan besar dalam penanganan penyakit ini, senyawa tersebut adalah artemisinin yang terdapat pada tanaman Artemisia (Ebadi, 2007).

Saat ini Artemisia annua L. merupakan tumbuhan yang satu-satunya mempunyai kadar artemisinin yang cukup tinggi di alam yaitu 0,1-1,8 \% bahkan dengan menggunakan klon Cina dan Vietnam kandungannya dapat mencapai 2 $\%$ (Ferreira et al., 2005). Tanaman ini merupakan tanaman subtropis yang telah tersebar di Malaysia dan Vietnam (Kardinan, 2006). Meskipun demikian terdapat jenis artemisia yang tersebar di Indonesia, salah satunya Artemisia vulgaris L. namun, sejauh ini belum banyak dilakukan penelitian. Padahal tanaman ini berpotensi mengandung berbagai senyawa metabolit sekunder salah satunya artemisinin (Kasmiyati, Herawati dan Kristiana, 2008). 
Masalah yang dihadapi dalam pembudidayaan tanaman obat ini adalah biji Artemisia mempunyai viabilitas yang sangat rendah dan tidak mempunyai masa dormansi. Selain itu tanaman ini hanya diperbanyak secara konvensional melalui stek anakan atau secara generatif melalui biji (Kardinan, 2006). Hal ini berdampak terhadap bibit yang tidak seragam, variasi bibit yang dihasilkan dengan biji juga sangat mempengaruhi kandungan zat bioaktif yang dihasilkan (Ermayanti et al., 2002).

Perbanyakan A. vulgaris dapat dilakukan melalui teknik kultur jaringan. Dengan teknik kultur jaringan ini, dapat dihasilkan bibit bermutu, seragam dan bebas penyakit dalam jumlah banyak dan waktu yang singkat (Wulansari et al., 2013). Beberapa cara dalam teknik kultur jaringan adalah dengan, kultur sel, kultur protoplas, kultur organ dan embriogenesis somatik dan kultur kalus (George dan Sherrington, 1984).

Kalus merupakan jaringan yang belum terdiferensiasi dan terbentuk ketika sel tanaman mengalami pembelahan yang tidak teratur, sebagai akibat dari perlukaan pada permukaan eksplan dan pengaruh perlakuan zat pengatur tumbuh yang diberikan pada media kultur (Zulkarnain, 2009). Dalam budidaya kultur jaringan, menginduksi kalus merupakan salah satu langkah penting karena, kalus mempunyai pertumbuhan yang abnormal dan berpotensi untuk berkembang menjadi akar, tunas dan embrioid lebih cepat, yang nantinya akan dapat membentuk plantlet (Suryowinoto, 1996).

Menurut Sumardi (1996) beberapa faktor diketahui mampu mempengaruhi dalam induksi kalus seperti ketersediaan energi, tempat eksplan tumbuh dan kehadiran zat pengatur tumbuh terutama auksin golongan 2,4-D. Penelitian mengenai induksi kalus sebelumnya telah dilakukan oleh Bustami (2011) konsentrasi efektif untuk induksi kalus kacang tanah dengan menggunakan 1,5 mg/L 2,4-D, sedangkan Rahayu, Solihatun dan Anggarwulan (2003), dengan menggunakan konsentrasi $0,5 \mathrm{mg} / \mathrm{L}$ 2,4-D efektif dalam induksi kalus Acalipta incica, Rusdianto dan Indrianto (2012) menggunakan konsentrasi $2 \mathrm{mg} / \mathrm{L}$ 2,4-D efektif dalam induksi kalus pada Daucus carota. Penelitian ini dilakukan dengan tujuan menginduksi kalus $A$. vulgaris dengan beberapa konsentrasi 2,4-D.

\section{Metode Penelitian}

Penelitian ini menggunakan metode eksperimen dengan Rancangan Acak Lengkap (RAL) 7 perlakuan yaitu : kontrol (tanpa 2,4-D), 2,4-D 0,25 mg/L, 2,4-D 0,50 mg/L, 2,4-D $\quad 0,75 \mathrm{mg} / \mathrm{L}, 2,4-\mathrm{D} \quad 1,00$ $\mathrm{mg} / \mathrm{L}, 2,4-\mathrm{D} \quad 1,25 \mathrm{mg} / \mathrm{L}, 2,4-\mathrm{D}$ 1,50 mg/L. Masing-masing perlakuan dilakukan pengulangan sebanyak 4 ulangan. Total unit percobaan adalah $7 \times 4=28$

\section{Alat dan Bahan}

Alat dan bahan yang digunakan dalam penelitian adalah alat dan bahan yang standar digunakan dalam kultur jaringan. Eksplan yang digunakan adalah bagian pucuk dari daun A. vulgaris.

\section{Cara Kerja}

Cara kerja terdiri dari beberapa tahap yaitu sterilisasi alat, pembuatan larutan stok, pembuatan media tanam, persiapan eksplan, penanaman eksplan, pengamatan, dan analisis data

\section{Pengamatan}

Pengamatan dilakukan setelah 12 minggu masa tanam meliputi :

a. Persentase hidup eksplan

Pengamatan dilakukan setelah eksplan berumur 12 minggu setelah tanam (mst) dengan kriteria kalus yang tumbuh dan tidak mati pada masing-masing perlakuan, dihitung dengan menggunakan persamaan :

Persentase hidup

$=$ Jumlah eksplan yang hidup $\times 100 \%$ Jumlah ulangan 
b. Tekstur dan warna kalus

Pengamatan tekstur kalus dilakukan secara visual diakhir pengamatan $12 \mathrm{mst}$ baik kalus embriogenik maupun kalus non embriogenik. Warna kalus diamati secara visual meliputi hijau, hijau kekuningan, coklat dan putih.

c. Berat basah kalus

Berat basah kalus ditimbang dengan timbangan analitik pada akhir pengamatan $12 \mathrm{mst}$.

\section{Analisis data}

Analisis data secara deskriptif meliputi persentase hidup eksplan tekstur dan warna kalus. Sedangkan data kuantitatif berupa berat basah kalus dianalisis dengan menggunakan analisis ragam berdasarkan uji $\mathrm{F}$ taraf $5 \%$ dan $1 \%$ dan apabila terdapat beda nyata dilanjutkan dengan uji DNMRT taraf 5\% dan $1 \%$.

\section{Hasil dan Pembahasan}

Dari penelitian yang telah dilakukan mengenai induksi kalus A. vulgaris dengan pemberian beberapa konsentrasi 2,4Dichlorophenoxyacetic acid (2,4-D) didapatkan hasil sebagai berikut.

\section{Persentase hidup eksplan}

Persentase hidup eksplan daun A. vulgaris pada medium MS dengan pemberian 2,4-D diamati pada 12 minggu setalah tanam disajikan pada Tabel 1.

Tabel 1 menunjukan bahwa eksplan berupa daun $A$. vulgaris dapat hidup pada medium MS yang diberikan zat pengatur tumbuh berupa 2,4-D didalamnya, karena pemberian zat pengatur tumbuh dianggap cukup untuk pertumbuhan eksplan. Pengamatan terhadap eksplan A. vulgaris sampai 12 minggu setalah tanam menunjukan bahwa pemberian 2,4-D memberikan pengaruh berbeda dibandingkan tanpa pemberian 2,4-D. Dengan pemberian 2,4-D respons hidup $A$. vulgaris mencapai $100 \%$, sedangkan perlakuan kontrol yang tanpa diberi 2,4-D menunjukan tidak adanya respons hidup.
Tabel 1. Persentase hidup eksplan daun $A$. vulgaris pada medium MS dengan pemberian 2,4-D pada 12 minggu setelah tanam

\begin{tabular}{lc}
\hline \multicolumn{1}{c}{ Perlakuan } & $\begin{array}{c}\text { Persentase } \\
\text { hidup } \\
\text { eksplan } \\
(\%)\end{array}$ \\
\hline A. Kontrol (tanpa 2,4-D) & 0 \\
B. $0,25 \mathrm{mg} / \mathrm{L} 2,4-\mathrm{D}$ & 100 \\
C. $0,50 \mathrm{mg} / \mathrm{L} 2,4-\mathrm{D}$ & 100 \\
D. $0,75 \mathrm{mg} / \mathrm{L} 2,4-\mathrm{D}$ & 100 \\
E. $1,00 \mathrm{mg} / \mathrm{L} \mathrm{2,4-D}$ & 100 \\
F. $1,25 \mathrm{mg} / \mathrm{L} 2,4-\mathrm{D}$ & 100 \\
G. $1,50 \mathrm{mg} / \mathrm{L} 2,4-\mathrm{D}$ & 100 \\
\hline
\end{tabular}

Lizawati, Neliyati Dan Desfira (2012) menyatakan konsentrasi zat pengatur tumbuh 2,4-D yang diberikan ke dalam media kultur tersebut mampu menginduksi sel-sel yang berpotensi untuk melakukan pembelahan secara terus menerus. Tanpa pemberian zat pengatur tumbuh 2,4-D eksplan tidak memperlihatkan respons hidup, ditandai dengan tidak adanya bagian sel yang berkembang dan eksplan berubah warna menjadi kehitaman. Pierik (1987) menjelaskan mekanisme kerja 2,4-D dalam pembentukan kalus yaitu disebabkan adanya rangsangan luka, rangsangan tersebut menyebabkan kesetimbangan pada dinding sel berubah arah, sebagian protoplas mengalir keluar sehingga mulai terbentuk kalus yang berisi sel-sel aktif mengadakan pembelahan seperti jaringan penutup luka.

Menurut Collin dan Edward (1998), level zat pengatur tumbuh merupakan faktor yang sangat menentukan keberhasilan hidup eksplan berupa pertumbuhan kalus, suspensi sel dan diferensiasi. Selain itu, keberhasilan eksplan untuk dapat hidup dalam kegiatan kultur jaringan juga dipengaruhi oleh jenis, umur dan ukuran eksplan yang digunakan.

Eksplan yang digunakan adalah bagian pucuk dari $A$. vulgaris yang merupakan salah satu bagian meristematik, Krisnamoorthy (1981) menyatakan daerah meristematik yang mengandung hormon endogen berupa auksin, giberelin, dan 
sitokinin yang tinggi, dapat digunakan sebagai sumber eksplan karena sel nya masih aktif membelah.

Tekstur dan warna kalus
Pengamatan terhadap tekstur dan warna kalus eksplan daun A. vulgaris pada medium MS dengan pemberian 2,4-D diamati pada 12 minggu setelah tanam. Tekstur dan warna kalus disajikan pada tabel berikut:

Tabel 2. Tekstur dan warna kalus eksplan daun A. vulgaris pada medium MS dengan pemberian 2,4-D pada 12 minggu setelah tanam

\begin{tabular}{|c|c|c|}
\hline Perlakuan & Tekstur kalus & Warna kalus \\
\hline A. Kontrol (tanpa 2,4-D) & - & - \\
\hline B. $0,25 \mathrm{mg} / \mathrm{L} 2,4-\mathrm{D}$ & Kompak & Hijau kekuningan \\
\hline C. $0,50 \mathrm{mg} / \mathrm{L} 2,4-\mathrm{D}$ & Kompak & Hijau kekuningan dan hijau kecoklatan \\
\hline D. $0,75 \mathrm{mg} / \mathrm{L} 2,4-\mathrm{D}$ & Remah & Hijau kekuningan dan hijau kecoklatan \\
\hline E. $1,00 \mathrm{mg} / \mathrm{L} 2,4-\mathrm{D}$ & Remah & Hijau kekuningan dan putih kekuningan \\
\hline F. $1,25 \mathrm{mg} / \mathrm{L} 2,4-\mathrm{D}$ & Remah & $\begin{array}{l}\text { Kuning kecoklatan, putih kekuningan, } \\
\text { dan putih kehijauan }\end{array}$ \\
\hline G.1,50 mg/L2,4-D & Remah & $\begin{array}{l}\text { Hijau kekuningan, putih kekuningan, } \\
\text { putih kehijauan, }\end{array}$ \\
\hline
\end{tabular}

Berdasarkan Tabel 2, diperoleh tekstur dan warna kalus yang cukup bervariasi. Zat pengatur tumbuh dapat mempengaruhi kualitas dan kuantitas yang terbentuk untuk menginduksi embriogenesis somatik daun A. vulgaris. Hasil pengamatan menunjukan semakin tinggi konsentrasi 2,4-D yang diberikan semakin cerah warna kalus yang terbentuk dan kalus bertekstur remah (friabel). Hal ini diduga oleh pemberian konsentrasi 2,4-D mempengaruhi tekstur kalus, dimana auksin ini akan merangsang sel-sel untuk terus berkembang, akibatnya semakin tinggi pemberian 2,4-D semakin cepat kemampuan sel untuk membelah membentuk kalus yang remah. Rahayu, Solichatun dan Anggarwulan (2003) menyatakan peningkatan konsentrasi auksin akan meningkatkan friabilitas kalus. Hal ini sejalan dengan penelitian Yelnititis dan Bermawie (2000) yang mendapatkan hasil pertumbuhan kalus yang diberikan zat pengatur tumbuh 2,4-D akan menghasilkan kalus yang bertekstur kompak sampai bertekstur remah (friabel) dan subkultur kalus kedalam media tumbuh yang sama mendorong terbentuknya kalus embriogenik. Menurut Fatmawati (2008) kalus yang sebagian besar bertekstur remah pada eksplan daun $A$. апnиa disebabkan oleh penggunaan 2,4-D dalam media kultur.

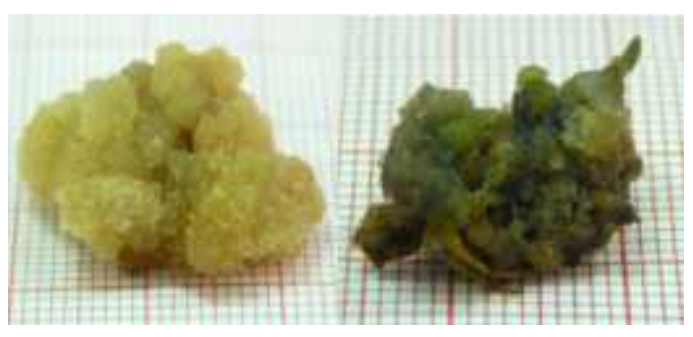

(a)

(b)

Gambar 1. Tekstur dan warna kalus $A$. vulgaris pada 12 minggu setelah tanam : (a) kalus dengan tekstur remah warna putih kekuningan pada perlakuan E (1,00 mg/L 2,4-D) (b) kalus dengan tekstur remah dan warna hijau kekuningan pada perlakuan $\mathrm{C}$ (0,50 mg/L 2,4-D).

Menurut Fatmawati, Nurhidayati dan Jadid (2008), warna dan tekstur kalus merupakan indikasi dimulainya respons organogenesis, karena sebagai akibat 
perlukaan pada permukaan eksplan, massa sel mengalami proliferasi menjadi kalus yang kemudian nantinya membentuk jaringan parenkim atau jaringan dasar yang dapat bersifat meristematik dan berdiferensiasi ke bentuk yang lebih spesifik.

Warna putih hingga kekuningan merupakan salah satu sebagai ciri kalus yang dapat berkembang menjadi embriogenik (Yelnititis, 2012). Warna hijau pada kalus mengindikasikan keberadaan klorofil dalam jaringan. Kalus bewarna kekuningan, putih kekuningan serta putih dan bertekstur friabel merupakan ciri kalus yang membentuk embrio somatik (Riyadi dan Tirtoboma, 2004).

\section{Berat basah kalus}

Hasil perhitungan rata-rata berat basah kalus eksplan daun A. vulgaris pada medium MS dengan pemberian 2,4-D diamati pada 12 minggu setelah tanam. Rata-rata berat basah kalus disajikan pada Tabel 3.

Tabel 3. Berat basah kalus eksplan daun A. vulgaris pada medium MS dengan pemberian 2,4-D pada 12 minggu setelah tanam

\begin{tabular}{lc}
\hline \multicolumn{1}{c}{ Perlakuan } & $\begin{array}{c}\text { Rata-rata } \\
\text { berat basah } \\
(\mathrm{g})\end{array}$ \\
\hline A. Kontrol (tanpa 2,4-D) & $0,00 \mathrm{a}$ \\
B. $0,25 \mathrm{mg} / \mathrm{L} 2,4-\mathrm{D}$ & $0,17 \mathrm{~b}$ \\
C. $0,50 \mathrm{mg} / \mathrm{L} \mathrm{2,4-D}$ & $0,31 \mathrm{c}$ \\
D. $0,75 \mathrm{mg} / \mathrm{L} \mathrm{2,4-D}$ & $0,37 \mathrm{c}$ \\
E. $1,00 \mathrm{mg} / \mathrm{L} 2,4-\mathrm{D}$ & $0,50 \mathrm{~d}$ \\
F. $1,25 \mathrm{mg} / \mathrm{L} \mathrm{2,4-D}$ & $0,57 \mathrm{de}$ \\
G.1,50 mg/L 2,4-D & $0,70 \mathrm{e}$ \\
\hline
\end{tabular}

Berdasarkan hasil analisis data pada Tabel 3 , penambahan berbagai konsentrasi 2,4-D memberikan pengaruh yang berbeda nyata terhadap peningkatan rata-rata berat basah kalus $A$. vulgaris, perlakuan tanpa 2,4-D memberikan hasil yang berbeda dengan perlakuan yang ditambahkan konsentrasi
2,4-D, jika diberikan konsentrasi 2,4-D rata-rata berat basah kalus semakin tinggi.

Perlakuan terbaik untuk

peningkatan berat basah kalus terdapat pada konsentrasi 1,25 $\mathrm{mg} / \mathrm{L} \quad 2,4-\mathrm{D}$ dan 1,50 $\mathrm{mg} / \mathrm{L}$ 2,4-D, hal ini disebabkan karena aktifitas 2,4-D yang mempengaruhi pertumbuhan eskplan. Wattimena (1988) menyatakan mekanisme kerja auksin salah satunya adalah pemanjangan sel. Auksin mendorong elongasi sel pada koleoptil dan ruas-ruas tanaman. Elongasi sel terutama terjadi pada arah vertikal dan diikuti dengan pembesaran sel dan peningkatan bobot basah.

Ajijah et al. (2010), menyatakan bobot berat basah eksplan digunakan untuk mengukur petumbuhan tanaman baik secara in vitro maupun in vivo. Peningkatan bobot basah ini sejalan dengan penelitian Rahayu, Solichatun dan Anggarwulan (2003), yang mendapatkan hasil yaitu penambahan zat pengatur tumbuh 2,4-D dapat meningkatkan rerata berat basah kalus yang berbeda nyata dari tanaman Acalypha indica. Dewita (2015) juga melaporkan pengaruh pemberian konsentrasi 2,4-D terhadap pertambahan rata-rata berat segar kalus $A$. vulgaris. Semakin tinggi penambahan konsentrasi 2,4-D, maka akan semakin tinggi peningkatan rata-rata berat segar kalus. Peningkatan tersebut dipicu oleh daya aktifitas 2,4-D yang sangat tinggi, sehingga jaringan menjadi stres dan akan menyebakan terjadi pembelahan sel secara terus-menerus di dalam jaringan yang akhirnya berpengaruh terhadap ukuran kalus.

Santoso dan Nursandi (2004) menyatakan arah perkembangan kultur ditentukan oleh interaksi dan perimbangan antara zat pengatur tumbuh yang diproduksi oleh sel tanaman secara endogen, di dalam eksplan itu sendiri sudah ada zat pengatur tumbuh endogen, akan tetapi dalam pertumbuhan dan perkembangan tanaman secara in vitro zat pengatur tumbuh eksogen masih dibutuhkan. 


\section{Kesimpulan}

Dari penelitian yang telah dilakukan mengenai induksi kalus daun A. vulgaris dengan pemberian beberapa konsentrasi 2,4-D dapat disimpulkan bahwa pemberian konsentrasi 2,4-D 0,25-1,5 $\mathrm{mg} / \mathrm{L}$ mampu menginduksi kalus A.vulgaris, dengan tekstur kompak sampai dengan remah, dan warna kalus yang dihasilkan adalah hijau kekuningan, hijau kecoklatan, kuning kecoklatan, putih kekuningan dan putih kehijauan. Konsentrasi 1,5 mg/L 2,4-D efektif dalam peningkatan bobot basah kalus A. vulgaris.

\section{Ucapan Terima Kasih}

Terima kasih penulis ucapkan kepada Dr. Zozy Aneloi Noli, Suwirmen, MS, Dr. Anthoni Agustien, Zuhri Syam, MP, Dr. Tesri Maideliza yang telah memberi banyak masukan dan saran dalam penulisan artikel ini.

\section{Daftar Pustaka}

Ajijah N., I. Darwati., Yudiwanti dan Roostika. 2010. Pengaruh Suhu Inkubasi Terhadap Pertumbuhan dan Perkembangan Embrio Somatik Purwoceng (Pimpinella pruatjan Molk.) Jurnal LITRI 16 (20) : 56-6.

Bustami, U. M. 2011. Penggunaan 2,4-D untuk Iinduksi Kalus Kacang Tanah. Media Litbang Sulteng IV (2) : 137-141

Collin, H.A dan S. Edwad. 1988. Plant Cell Culture. BIOS Scientific Publisher. United Kingdom.

Dewita, R. 2015. Respons Eksplan Daun
Artemisia Vulgaris
L.Terhadap Pemberian Beberapa
Konsentrasi Benzyl Amino Purine (BAP) Dan2,4-
Dichlorophenoxyacetic Acid (2,4- D). Skripsi Sarjana Biologi. Universitas Andalas. Padang.

Ebadi, N. 2007. Pharmacodynamic Basic of Herbal Medicine. CRC Press. London New York Washington D.C.726 p.
Ermayanti, T. M., Y. Andri., D. R. Wulandari dan E. Al Hafiidz. 2002 Mikropropagasi Artemisia cina dan Artemisia annua. Seminar Nasional Pemanfaatan dan Pelestarian Plasma Nutfah. Bogor 3-4 September 2002.

Fatmawati, A. 2008. Kajian Konsentrasi BAP dan 2,4-D terhadap Induksi Kalus Tanaman Artemisia annua $L$. secara In Vitro. Skripsi. UNS. Surakarta.

Fatmawati, T. A., T. Nurhidayati dan N. Jadid. 2008. Pengaruh Kombinasi Zat Pengatur Tumbuh IAA dan BAP pada Kultur Jaringan Tembakau Nicotiana Tabacum L. Var. Prancak 95. Institut Teknologi Sepuluh November. Surabaya

Ferreira, J. F. S., J. C. Laughlin., N. Delabays and P. M. de Magalhaes. 2005. Cultivation and genetics of Artemisia aпnиa L. for Increase Production of The Antimalarial Artemisinin. Plant Genetic Resources III (2) : 206-229.

George, E. F. dan Sherrington. 1984. Plant Propagation by Tissue Culture. Eastern Press. Reading Berks.

Harijanto, P.N. 2011. ACT Sebagai Obat Pilihan Malaria Ringan di Indonesia. Hasil Penelitian SMF Ilmu Penyakit Dalam RSU Bethesda Tomohon, Sulawesi Utara. CDK 183. 38 (2).

Ishak. 2005. Analisis Bibliometrika Terhadap Artikel Penyakit Malaria di Indonesia tahun 1970-April 2004 Menggunakan Database Online Pubmed. Jurnal Studi Perpustakaan dan Informasi 1 (2)

Kardinan, A. 2006. Tanaman Artemisia Penakluk Penyakit Malaria. http://www.kompas.com/kompascet ak/0604/20/ilpeng/2592372.htm.Di akses tanggal 22 Januari 2015.

Kasmiyati., S. Herawati dan M. M. Kristiana. 2008. Pertumbuhan Artemisia vulgaris Secara Kultur 
Pucuk pada Medium dengan

Kandungan Mioinositol dan

Ekstrak Khamir. Biota Vol. 13 (2).

Krishnamoorthy. 1981. Plant Growth Subtances. Aplications and Agriculture. MC Graw

Hill Books CO. New York

Lizawati, Neliyati, R. Desfira. 2012. Induksi Kalus Eksplan Daun Durian (Durio zibethinus Murr cv Selat Jambi) pada beberapa kombinasi 2,4-D dan BAP. 2012. ISSN : 2302-6472 1 (1)

Pierik, R.L.M., 1987. In Vitro Culture of Higher Plants. Martinus Nijhaf Publisher, Dorroocht. The Netherland.

Rahayu, B,. Solichatun, dan E. Anggarwulan. 2003. Pengaruh 2,4D Terhadap Pembentukan dan PertumbuhanKalus Serta Kandungan Flaponoid Kultur Kalus Acalipta Indica L. Biofarmasi 1(1) : 1-6.

Riyadi, I dan Tirtoboma. 2004. Pengaruh 2,4-D Terhadap Induksi Embrio Somatik Kopi Arabica. Buletin Plasma Nutfah 10 (2) : 82-89.

Rusdianto dan Indrianto. 2012. Induksi Kalus Embriogenik pada Wortel (Daucus carota) dengan menggunakan 2,4-D. Jurnal Bionature 13 (2) : 136-140

Santoso dan F. Nursandi. 2004. Kultur Jaringan Tanaman. Universitas Muhammadiyah Malang Press. Malang.

Suryowinoto, M., 1996. Pemuliaan Tanaman Secara In Vitro. Pusat Antar Universitas Bioteknologi. UGM. Yogyakarta $252 \mathrm{~h}$.

Sumardi. 1996. Penggunaan Arang Aktif pada Beberapa Komposisi NAA dan BAP dalam Kultur Durian (Durio Zibethinus Murr.) secara In Vitro. Tesis S2. Program Pascasarjana Universitas Andalas. Padang.

Wattimena, G.A. 1988. Zat Pengatur Tumbuh Pada Tanaman. Laboratorium Kultur Jaringan
Pusat Antar Universitas Bioteknologi IPB. Bogor.

Wulansari, A., A.F Martin., D.E Rantau dan T.M Ermayanti. 2013. Perbanyakan Beberapa Aksesi Talas (Colocasia esculenta L.) Diploid Secara Kultur Jaringan dan Konservasinya Mendukung Diversifikasi Pangan. Seminar Nasional Riset Pangan, Obat-obatan dan Lingkungan Kesehatan. LIPI.

Yelnititis. 2012. Pembentukan Kalus Remah dari Eksplan Daun Ramin (Gonystylus bancanus (Miq) Kurz.). Jurnal Pemuliaan Tanaman Hutan. 6 : $181-194$.

Zulkarnain. 2009. Kultur Jaringan Tanaman. Bumi Aksara. Jakarta 
Jurnal Biologi Universitas Andalas (J. Bio. UA.)

4(4) - Desember 2015: 216-222 (ISSN : 2303-2162) 